\title{
THE USE OF INTERNET TO INCREASE STUDENT MOTIVATION IN THE FOREIGN LANGUAGE LEARNING PROCESS
}

\author{
Aleksandra Gagić, \\ Milica Zelić, \\ Milica Čolović
}

Singidunum University,

Belgrade, Serbia

Correspondence:

Aleksandra Gagić

e-mail:

agagic@singidunum.ac.rs

\begin{abstract}
:
It is very difficult to keep your students motivated all the time. Nowadays, it may become even more challenging to do that. The millennial generation spends many hours on the computer, often the Internet.How to motivate your students to value class activities, and without external pressure, to carry them out on their own?.In this paper we agree that teachers should use digital tools in the teaching process and to combine them with well known methods and approaches. Teachers today tend to classify students as not being able to concentrate. We should help our students in this situation using innovative digital aids; they are using them a lot on a daily basis, so, in this way, we can get closer to them. Using something similar in our classroom may make lessons more appealing to them, and it can surely motivate them to learn. We should be aware of the fact that nowadays students prefer looking at a screen than books, so we should use new resources.
\end{abstract}

Keywords:

motivation, learning, internet, millenials, methods.

\section{INTRODUCTION}

There are various definitions of motivation.It is defined as a psychological process that affects the initiation, direction, intensity, and duration of certain behavior [1]. To be motivated means to be moved to do something. The one who feels no inspiration to act is characterized as unmotivated, whereas someone who is energized or activated towards an end is considered motivated [2]. According to another author motivating is when the desire to learn something is stimulated [3]. There are two major types of motivation:

- Intrinsic motivation - doing of an activity for its inherent satisfaction rather than for some separable consequence.It exists within individuals. It is also noticed that with each advancing year age in schools, intrinsic motivation becomes weaker.

- Extrinsic motivation -is a construct that pertains whenever an activity is done in order to attain some separable outcome. This typr contrasts with intrinsic motivation, which refers to doing an activity simply for the enjoyment of the activity itself, rather than its instrumental value. Given that many of the educational activities 
prescribed in schools are not designed to be intrinsically interesting, a central question is how to motivate students to value and self-regulate such activities, and without external pressure, to carry them out on their own [2].

Since the motivation has an impact on learning styles, there are:

- Deep learners -intrinsically motivated students who like difficult and complex subjects.

- Strategic learners are the students motivated primarily by the rewards. They like competing with others, have good grades, but will not make an effort unless are rewarded.

- Surface learners - their motivation is avoiding the failure. Teachers should help them gain confidence in their abilities [4].

Middleton, Littlefield and Lehrer have suggested the model of intrinsic motivation. They said that in the first stage, students are judging whether the activity is interesting or not. If it is not, then they think about two factors: stimulation and personal control. If the activity possesses these two factors, then it becomes interesting for them. But, if over time, the activity provides little stimulation or control, students remove it from their mental list of interesting activities [5].

These authors were focused on the ways in which teachers attempted build student motivation into their lessons, and the belief systems of teachers as compared to those of their students. The results showed that when teachers can predict their students' beliefs, they are more successful in motivating them for learning.

\section{MILLENIALS}

The millennial generation is also called generation $\mathrm{Y}$, the Net generation, and also the NeXt generation. The generation which spends many hours on the computer, often the Internet, interacting with peers, doing schoolwork, playing games, shopping, and otherwise entertaining themselves.

They are self-confident, extremely social, goal-oriented, but, on the other hand, impatient, materialistic, and self-centered. These people can be challenging to deal with. Our lessons are not inspiring enough for them and that is why they are not motivated and do not respect them, but, we can reach them if we adjust our classes to their interests [3].
Although this is generally true, our opinion is that they do not have such a good interaction with peers, they are not extremely social, but we would definitely agree that they are self-centered.

It is very difficult to keep your students motivated all the time. Nowadays, it may become even more challenging to do that. Teachers rely on outdated approaches and methods, use old books, and, generally, are not willing to change much in their classes, especially those working in schools which do not have any modern equipment. On the other hand, students belonging to millennial generation, accustomed to all sorts of digital devices, find it very easily to lose any motivation in such circumstances. In order to gain students' attention, teachers need to make some changes when it comes to their lessons. How to keep your students motivated? There are various strategies we could use .

\section{STRATEGIES FOR MOTIVATING STUDENTS}

The students more motivated want to learn more, so they achieve more.

- Use different materials

Bringing technology into our lessons is a great way to motivate students.

Modern time and modern education require modern and innovative materials:

- Use of interactive boards and tablets

- The possibility of learning through the Internet; various platforms for learning and certain android applications

- Contemporary audio-visual and multimedia teaching aids

In this way students are developing critical thinking and research abilities, and are motivated to research and find information on their own.

Computer is a powerful device, and, if it is equipped with software and the Internet it can replace various teaching aids.

Interactive whiteboard is widely used in the world. They make classes much more interesting, improve the quality of teaching, and make students participate actively. Some of its main characteristics are displaying of the videos, showing pictures with great resolution, the usage of educational software.

Tablets are becoming the main teaching aids in modern classrooms. In other words, tablets are computers 
but with touch screens. The advantages they give in the classroom are various since a lot of useful applications can be installed.

Multimedia classrooms are equipped with the various modern teaching aids, like computers, projectors, slide projectors with DVDs, video screens, smart boards, so that new information technology can be used. Multimedia should provide multitasking ( the ability to do more processes at the same time) and interaction.

Amazon echo is one of the most modern teaching aids. Its main characteristic is sensitivity to voice. That means that students can give it voice commands, ask questions and get answers, for example, about historical events, book content, but also get current information from the real world.

Samsung gear VR looks like glasses which enable the experience of virtual reality; so that students via this device can get better impression about the things they learn in the class.[6]

Our students use a lot of digital devices in their free time. As a consequence, they find the lectures boring. Teachers today tend to classify students as not being able to concentrate, unmotivated and very often it is talked about ADHD. What they can do to help students in this situation is for sure the usage of innovative digital aids; they are using them a lot on a daily basis, so, in this way, we can get closer to them. Using something similar in our classroom may make lessons more appealing to them, and it can surely motivate them to learn.

We should be aware of the fact that nowadays students prefer looking at a screen than books, so we should use new resources.

Of course, this is only one of the ways to keep our students motivated, not the only and possibly not the best way. Every teacher should search for the things that are the best for their classroom.

\section{METHODS AND APPROACHES}

According to Grammar-translation method,the goal is to learn foreign language in order to read its literature. The major focus is on reading and writing. Vocabulary is based on the reading texts. When it comes to accuracy, it is emphasized, and the grammar is taught deductively. The medium of instruction is the student's native language [7].

In the Direct Method, the classroom instruction was conducted only in the target language, and everyday vocabulary and sentences were taught, as well as speech and listening comprehension. The emphasis was on correct pronunciation and grammar, which was taught inductively.

In The Oral Approach and Situational Language Teaching the main point is that the language teaching begins with the spoken language. Material is thought orally before being presented in the written form. The language that is used in the classroom is the target language. New language points are introduced and practiced situationally.

According toAudio lingual method the language skills are learned more effectively if the items are represented in spoken form before presenting them in written form. Teaching a language in the first place means teaching the cultural system of the people speaking the target language.

In Communicative language teaching, the primary language function is interaction and communication, and primarily units of language are not its grammatical and structural features, but categories of functional and communicative meaning.

Total Physical Response is built around the coordination of speech and action; it is teaching language through physical activity.

Those who propose The silent way method claim that learning is easier if students discover or create than if they remember or repeat. (Richards \& Rodgers, 1986, p.99)

In the classrooms where Community Language Learning method is used, there is a lot of foreign language conversation. What is more important, students participate actively, they are encouraged to ask questions.

The goals of a Natural Approach class are based on the assessment of student needs. The course is planned around situations in which students will use the target language; teachers do not organize lessons around a grammatical syllabus.

Suggestopedia is a method developed by Bulgarian psychiatrist-educator Lozanov. He describes Suggestology, the science from which suggestopedia is derived, as being concerned with the systematic study to which humans are responding. The main focus is on decoration, furniture, arrangement of the classroom, usage of music, and the authoritative behaviour of the teacher [7].

Based on all these methods and approaches, teachers can create an ideal mixture for their classroom. 


\section{DEFINE THE OBJECTIVES}

On the level of the subject, this means that teacher should define the objectives at the beginning of the year. When you explain to your students the rules, and your expectations of them, you avoid any confusing situations and your students stay motivated for work [8].

It is of high importance to start every lesson with a good plan, and clear, reachable goals. If you want your students to be motivated and to participate all the time, you should involve them in every part of your lesson. Writing down a plan of your lesson on the board gives your students the chance to see where are you "taking" them (when it comes to teaching). In that way, they are highly motivated to let you be their leader, and they will surely leave the classroom satisfied.

The success of every task lies in giving clear instructions. A good teacher should be clear when setting a task, but it is also very important to give your students time to prepare and to ask some additional questions if they still do not understand. In that way teacher gets a classroom full of motivated students, who will, if not give the right answers to the task, at least try to solve it. Students find it very important to have a clear idea of what they are supposed to do, and otherwise, they would feel highly frustrated if they do not succeed because they had not understood the task in the first place [9].

\section{CREATE A THREAT-FREE ENVIRONMENT}

The key words for this section are positive reinforcement. Teachers should set boundaries and explain their students that they are responsible for their actions, but, teachers should not build the relationship with students based on the things they are not allowed to do. Learning in the threat-free environment is much more motivating for students. Creating a safe environment and showing your students that you believe in them will create the atmosphere full of joy and motivation. In this way students are willing to fulfill teacher's expectations [8].

If we remember the affective-filter hypothesis, it will also confirm us that the students learn when relaxed.

Positive reinforcement is adding a pleasant stimulus to intensify certain behavior.

Negative reinforcement is removing an aversive stimulus to enhance a behavior.

The goal of punishment is to make an undesired behavior less likely to happen, continue, or strengthen in the future. The difference is that reinforcement aims to increase a behavior, while punishment wants to decrease a behavior. Since punishment is proven to be actually harmful to brains, it is better to use reinforcement, even the negative [10].

\section{CHANGE YOUR SCENERY}

Can you remember early school days and the feeling of pure excitement when teacher took you outside and gave her lecture in the park or the museum and various other places?

Of course that the classroom is the most appropriate place for learning, but spending every day in the same place can make students feel a bit bored. To keep your students motivated to learn, you should always bring something new to your classes. Students could be taken out on some kind of an educational trip, to the library, or simply to the park. A good idea is also to bring in some speakers, as guests to your class [8].

Our brains like experiencing new and different things!

\section{OFFER VARIED EXPERIENCES}

In order to help students to stay engaged and pay attention to lessons, teachers should offer a variety of experiences during the class. In this way, even if they did not get the chance to know all of their students well, they will for sure focus them on the things they like best. Successful lesson is a perfect mix-up of different tasks for students with different preferences.

This is the way to maintain order in the classroom [10].

An essential thing is to teach students critical thinking and to make improvements while thinking. Teacher can create this environment with lectures, discussions, case studies, role playing, field work, and many other techniques. Many teachers never give their students opportunity to ask questions, they are simply giving the answers. If we want to create natural critical learning environment, we should encourage our students to compare, apply, evaluate, analyze, but never to simply listen and memorize [11].

One additional piece of advice for the teachers is always to have a plan B! If, for instance, teachers notice that the students are not listening, that they are bored, they should stop giving a lecture. It is better to ask students 
what they would like to listen or talk about; and then, by talking about the topic of students' choice, teachers should still try to talk about the things related to the lesson.

\section{INVOLVE YOUR STUDENTS}

Teaching 'ex-cathedra' is outdated. It does not motivate students because they do not want to be passive all the time. If we really want to keep students motivated, we should involve them and let them be active.

Students are the center of the class and the teacher is only a guide. Letting them choose the activity, or, for example, a topic for discussion in the classroom will give them the sense of control and equality to the teacher [9]. Even the naughtiest students calm down when we let them be in charge.

Carol Ames wrote an article about how classroom environments influence students' views about the nature and purposes of learning. She said that of crucial importance is creating a connection between environment, goals and student motivation. In one part she also suggested that teachers should involve students in the lessons and decision making, and that is essential for creating 'positive motivation patterns' in children [12].

Giving students responsibility makes them motivated to meet the expectations. If they are aware of the fact that they are responsible for a certain classroom activity it gives them the sense of motivation [8].

\section{VARY THE SOCIAL DYNAMICS}

The social interaction can get students excited about things in the classroom and students might motivate one another to reach goal.Working in pairs or groups can be fun and motivating for students to try to find solutions to the problems, work on projects, do experiments, or simply exchange the ideas or opinions. To keep students' attention a teacher can set a variety of engaging activities thus creating a friendly atmosphere in which they can talk and move freely [9].

However, teachers should be careful not to force students, who like individual work the best, to join the group work.

\section{GET TO KNOW YOUR STUDENTS}

Getting to know your students is a lot more than just memorizing their names. Showing your students that you respect them as individuals and that you appreciate their work motivates them to work harder [8].

If you succeed in getting to know your students, you will also have the opportunity to relate the lesson material to the things they find interesting. In that way, motivation on the side of the students is inevitable.If you want them to be truly loyal to you, you should show that you care about them and their success. Before judging your students, try to understand what kind of person is each of them, introvert or extrovert, but also show interest for their lives outside the classroom, find out if they are dealing with any problems or having hard times, which may cause them having difficulties in studying, concentrating on lectures, etc. Also, if a student begins displaying a sudden change in behaviour, that should be a sign for the teacher to try and find out what problems he or she is having at the moment. If you decide to talk to a student about possible problems, it is very important not to do that in front of the whole class. Teachers should be careful with students, because it is really important to them how others see them.

According to Joshua Eyler, teaching is a challenging profession, but on the other hand, we can make it easier by finding out more about the ways our students learn. We can do the research in lot of fields, like developmental psychology, cognitive neuroscience, and anthropology.

\section{MAKE LEARNING FUN}

The most memorable classes are those in which teacher succeeded in combining learning and entertainment. Students of any age like fun and playing games. Positive competition in some cases can motivate students to try harder. It gives them the opportunity to interact with each other, show off their knowledge, but also to have fun.

\section{PRAISE}

One way to motivate your students is to get them take a hard look at themselves and determine their own strengths and weaknesses [8]. Everyone wants to succeed, and no one likes being criticized by the teacher. So, if you encourage self-reflection in students, they will be responsible for their success, and will be given a chance to shine. There is no better form of motivation than encouragement. Giving praise for a well-done job will be motivational for the whole class, the only thing a teacher 
should pay attention to is not to degrade others by praising one student. It is much better to observe a class as a team and encourage them all to achieve even better results. Simple words like 'well done' or 'thank you' build students'self-cofidence. If we apply this to a task-level, that means that teacher should give a task where the students can see the results of their effort.

That feeling of 'Yeah, I did it!', that 'a-ha' moment students get when they have done a difficult exercise, boosts their motivation [9].

\section{DON'T OVER CORRECT}

Over-correcting should be avoided, especially in speaking exercises. No one likes being interrupted and not listened to. That also has a bad impact on motivation. Over-correcting may cause that students become insecure and not believe in their own abilities. Good teachers rather explain that making mistakes is a natural part of learning. It is better to show our students that we are good listeners.

\section{BE A ROLE MODEL}

The best way to keep your students motivated is to share your enthusiasm. A teacher who is a role model to the students is the one that is excited about teaching, the one that loves the job, and loves students. This is the way of transferring motivation to students. The passion of the teacher motivates students [14]. According to Cavanagh teachers who really want to get students' attention, need to include emotions in their teaching style. In that way, students' persistence can be prolonged, they will make an effort, and stay focused and motivated for learning [15].

What is even more important is to explain your students that making mistakes is part of a learning process. Nothing is irreparable. It is perfectly normal to have ups and downs in learning,as well as in everyday life.

\section{CONCLUSION}

In this paper we all agree that supportive classroom environments, practical activities with a lot of carefully chosen digital tools combined with various methods and approaches, teachers' personal and professional qualities, interaction and encouragement are very helpful for the language learning process in the classroom.
In our opinion, what keeps students motivated is a motivated teacher. We should put a lot of energy and time; we should make an effort in order to create interesting lessons. It is important to offer the right amount of the challenge so that students feel motivated to learn and they do not get bored or discouraged.

\section{REFERENCES}

[1] B. Kordić, L. Babić, Uvod u psihologiju, Centar za primenjenu psihologiju, Beograd, 2014, pp. 34

[2] R.M. Ryan, E.L. Deci, Intrinsic and Extrinsic Motivations: Classic Definitions and New Directions.University of Rochester: Contemporary educational psychology 25, 2000, pp. $54-60$

[3] L. Nilson, Teaching at its Best: A Research-Based Resource for College Instructors. San Francisco: Jossey-Bass, 2016, pp.51

[4] https://cft.vanderbilt.edu/guides-sub-pages/motivating-students/

[5] J.A. Middleton, A Study of Intrinsic Motivation in the Mathematics Classroom: A Personal Constructs Approach. Journal for Research in Mathematics Education, volume\#26, No.3,1995, pp.254-279

[6] V. Jelić, Nastavna sredstva u savremenoj nastavi, Fakultet tehničkih nauka, Čačak, [Online] Available: www.ftn.kg.ac.rs/SIR

[7] J.C. Richards, T.S. Rodgers, Approaches and Methods in Language Teaching: A Description and Analysis. Cambridge: Cambridge University Press, 1986, pp.3-142

[8] 21 Simple ideas to improve student motivation, 2017, [Online].Avilable: (https://www.teachthought.com/pedagogy/21-simple-ideas-to-improvestudent-motivation/ )

[9] C.Cabal, How to keep your student motivated, British Council, 2017, [Online]. Avilable: (https://www. britishcouncil.org/voices-magazine/how-keepyour-students-motivated

[10] P.N. Chase, Teaching distinction between positive and negative reinforcement, The Behavior Analist, 2006, pp.113-115, [Online]. Available: (http://www. ncbi.nlm.nih.gov/pmc/articles/PMC2223171/)

[11] K. Bain, What the Best College Teachers Do, Harvard University Press, 2011, pp.

[12] C. Ames, Classrooms: Goals, Structures, and Student Motivation. Journal of educational psychology 84(3), 261, 1992.[Online] Available: https:// psycnet. apa.org/search

[13] J.R.Eyler, How Humans Learn: The Science and Stories behind effective college Teaching. West Virginia University Press, 2018 
[14] (https://www.teachhub.com/top-12-ways-motivatestudents )
[15] S.R. Cavanagh, The Spark of Learning: Energizing the College Classroom with the Science of Emotion. West Virginia University Press,2016,pp. 158-194 